\title{
The usage of a zeolitic composite for quality improvement of copper contaminated mining wastewaters
}

\author{
D. Dascălu $\cdot$ L. Pitulice $\cdot$ R. Ionel · O. Bizerea-Spiridon
}

Received: 13 January 2014/Revised: 24 April 2014/ Accepted: 13 May 2014/Published online: 27 May 2014

(C) Islamic Azad University (IAU) 2014

\begin{abstract}
In this paper, a new material based on zeolite has been investigated in an attempt to explore the possibility of using it as an efficient adsorbent of copper(II) from industrial wastewater. This composite material is composed of volcanic tuff (containing $83 \%$ zeolite) and cellulose in a 4 to 1 ratio. The performances of the new adsorbent composite have been examined against those of a common adsorbent, the zeolitic volcanic tuff. The adsorption studies were carried out in a batch process at room temperature, and the effect of various parameters (i.e., initial concentration, contact time, adsorbent dosage and $\mathrm{pH})$ was tested. The experimental data have been modeled with Langmuir, Freundlich and Temkin isotherms. The results correspond to Langmuir model showing a monolayer adsorption with a maximum adsorption capacity of $12.74 \mathrm{mg} \mathrm{g}^{-1}$ at $25{ }^{\circ} \mathrm{C}$. The copper adsorption onto zeolitic composite was well described by a pseudo-second order kinetic model. The experimental results indicate a superior adsorption of copper(II) onto the new adsorbent when compared against the common zeolite.
\end{abstract}

D. Dascălu · L. Pitulice $(\bowtie) \cdot$ O. Bizerea-Spiridon

Department of Biology-Chemistry, West University of Timişoara, 4 Parvan, 300223 Timişoara, Romania e-mail: ldpitulice@gmail.com

D. Dascălu · L. Pitulice · O. Bizerea-Spiridon

Laboratory of Advanced Research in Environmental

Protection (LCAM), 4 Oituz, 300086 Timişoara, Romania

R. Ionel

University "Politehnica" from Timişoara, 2 Parvan, 300223

Timişoara, Romania
Keywords Copper - Mine wastewater - Wastewater treatment $\cdot$ Zeolite $\cdot$ Adsorption

\section{Introduction}

The main sources of surface and groundwater pollution with heavy metals are of industrial origin. Among them, metal extraction and metallurgy, and also surface finishing, are the most severe (Cobbina et al. 2013; Stankovic et al. 2009). Even though in the last years mining operations have been upgraded with modern technology to minimize pollution, significant quantities of heavy metals such as $\mathrm{Cu}^{2+}, \mathrm{Hg}^{2+}, \mathrm{Cd}^{2+}, \mathrm{Pb}^{2+}$ and $\mathrm{As}^{3+}$ are impacting the environment either by different extraction processes or by piled mined waste. The toxic metals pollute the nearby water bodies, when released by exposed mine surfaces, and the groundwater as fluid mine tailings leach into the soil (Cobbina et al. 2013). These contaminants are often found in mining wastewaters, which discharged without prior treatment can contaminate the environment threatening human and animal health. Heavy metals are not biodegradable and have a tendency to accumulate in living organisms, causing various diseases and disorders (Al-Anber and Al-Anber 2008).

Copper $(\mathrm{Cu})$ is an essential nutrient necessary to human organism in trace amounts. However, over certain limits, it may generate a series of adverse effects. The most prevalent effects after short periods of exposure are gastrointestinal distress, nausea and vomiting (Araya et al. 2003; ATSDR 2004; ECHA 2008). In the long term, the use of copper contaminated water can cause hepatic and renal failure, cancer and even death (Gupte and Mumper 2009; Cobbina et al. 2013). 
According to one of the United Nations Environment Programme publications (UNEP 2009), the Balkans region represents the major European supplier of copper, lead and zinc due to mining and minerals processing. In an assessment study conducted by Panias (Panias 2006), Bulgaria, Turkey, Serbia and Montenegro, Romania and Macedonia were identified to be the most important copper producers in the Balkans.

Copper metallurgy is attested on the Romanian present territory since pre-Roman time. Large copper reserves, with a vast production potential and a long lifetime, exist here (Milu et al. 2002). Copper exploitation has grown in Western Romania (Rosia Poieni, Moldova Noua) due to massive copper ores present in Occidental Carpathians, especially Banat and Apuseni Mountains (Milu et al. 2002; Bostan 2013). For years, the substandard exploitation of region deposits and the following metal production has contributed to serious local and regional heavy metal contamination of the environment (mainly via waterways). The rural population from areas surrounding copper mines in Western Romania is largely dependent on hand-dug fountains, boreholes and surface water. All these sources are heavily contaminated with this metal. Besides active monitoring of tailings management facility, mine water treatment is one of the sustainable solutions for minimizing toxicants release (UNEP 2009).

Several methods for removing heavy metal ions from industrial effluents have been proposed and studied all over the world. They are based on precipitation (Kurniawan et al. 2006b; Fu and Wang 2011), ionic exchange (Barakat 2011), membrane filtration (ultrafiltration, reverse osmosis, electrodialysis, etc.) (Barakat 2011; Fu and Wang 2011), coagulation-electrocoagulation and flocculation $(\mathrm{Fu}$ and Wang 2011; Dermentzis et al. 2011; Butler et al. 2011). Lately, adsorption on different materials (Kurniawan et al. 2006a; Barakat 2011; Fu and Wang 2011) has become a thoroughly studied and used technique for pollutant removal from wastewater.

In order to be efficient, an adsorbent must possess certain attributes such as high affinity to target compound (in order to ensure an elevated removal degree); cost efficiency and regeneration capacity, and not at last, it should be environmentally safe. Lots of adsorbents have been investigated with the purpose of removing heavy metals from water: active carbon (Madhava Rao et al. 2006; Papandreou et al. 2007; Tumin et al. 2008; Patnukao et al. 2008; Chaudhuri et al. 2010; Yahaya et al. 2011), silicon dioxide (Tran and Roddick 1999), diatomite and apatite (De Castro Dantas et al. 2001), sawdust, sugarcane bagasse and other natural materials (Stankovic et al. 2009; Bedelean et al. 2009; Santos et al. 2011), different types of biomass (Kaewsarn 2002; Rangsayatorn et al. 2004; Horsfall and Spiff 2005; Solisio et al. 2006; Pane et al. 2008). Among them, natural and synthetic zeolites hold a significant place (Erdem et al. 2004; Gazola et al. 2006; Basaldella et al. 2007; Wu et al. 2008; Halimoon and Yin 2010; Karatas 2012). Natural zeolite sediments mainly consist of aluminum silicates with a three-dimensional structure made of $\mathrm{AlO}_{4}$ and $\mathrm{SiO}_{4}$ tetrahedrons. Only some natural zeolites such as heulandite, rich in silica (clinoptilolite), and mordenite are found in abundance. They possess the required purity for industrial applications. One of the most important environmental applications of zeolites reported in literature is wastewater treatment (Englert and Rubio 2005).

In Romania, natural zeolite, rich in readily exploitable clinoptilolite, is frequently found in Transilvania and Maramures basins. Applications of natural occurring and modified zeolitic tuff from these regions include environment remediation, clinical therapy and industrial domain (Bedelean et al. 2010; Smical et al. 2010; Anghel et al. 2012).

The present study aims at removing copper(II) ions from dilute solutions by adsorption onto an original composite material. This consists of zeolitic volcanic tuff to which another known adsorbent, cellulose, was added. Consequently, the zeolite selectivity and adsorption capacity toward copper(II) ions present in water samples (with similar content to mining wastewater) have been improved. Contact time, adsorbent dosage, copper initial concentration and solution $\mathrm{pH}$ are considered important variables in establishing the optimum adsorption conditions. A novelty of the paper resides in the usage of the potentiometric method based on Virtual Instrumentation concept for adsorption quantification. Electrochemical analysis used for the detection and measurement of various analytes from water combines a series of favorable characteristics such as high selectivity and sensitivity, reproducibility, ease of use, easy regeneration of the electrodes surface, suitability for automation and low cost (Mobin et al. 2010; Gadhari et al. 2011; Sanghavi et al. 2013).

The entire study has been carried out in the Laboratory of Advanced Research in Environmental Protection of the West University of Timisoara covering an 8-month period in 2012-2013.

\section{Materials and methods}

Materials and analysis techniques

The adsorptive study of the zeolitic composite, commercially available as BioZheolyth from Dacia Plant 

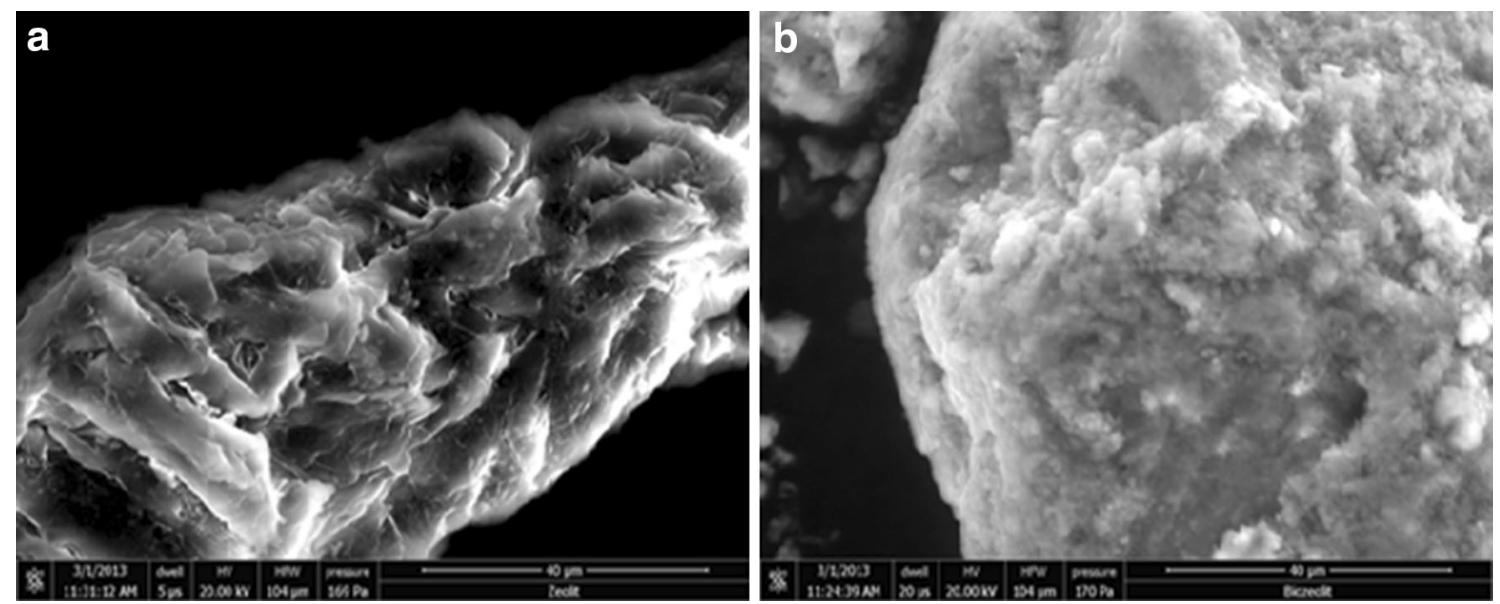

Fig. 1 SEM micrographs of zeolite (a) and BioZheolyth (b)

Company, Romania, was carried out in comparison with that of common zeolite available on the market from CEO EcoNatura Company, Romania. The BioZheolyth comprises mineralized volcanic tuff with high zeolite content (up to $83 \%$, mainly clinoptilolite) and cellulose in a 4 to 1 ratio. The used zeolite materials, both under ambient atmosphere storage and in aqueous solution, have a high, long-term structural stability. According to the manufacturer, the BioZheolyth has a shelf-life of 2 years in ambient conditions. The cost of the natural zeolite varies in quite large limits even from week to week depending on the manufacturer/supplier. Presently on Romanian market, the cost of zeolite ranges between 30 and 45 Euros/Kg while the cost of BioZheolyth stays between 70 and 90 Euros/Kg. The zeolite-cellulose composite performances on copper adsorption justify its usage even though it has a bit higher price than common zeolite.

Both adsorbents were characterized by SEM coupled with EDX, FTIR and BET techniques. The SEM-EDX data were collected using a FEI Inspect $S$ model scanning electron microscope. The infrared spectra were obtained with a Shimadzu Prestige-21 FTIR spectrophotometer in the range of $4,000-400 \mathrm{~cm}^{-1}$, using the $\mathrm{KBr}$ pellets technique. BET analysis provided the evaluation of the adsorbents-specific surface area along with pore volume and area distributions, using a Quantachrome Nova 1200e automated analyzer.

Copper(II) nitrate hemi(pentahydrate), hydrochloric acid $(\mathrm{HCl})$ and sodium hydroxide $(\mathrm{NaOH})$ of analytical grade were purchased from Sigma-Aldrich Chemie $\mathrm{GmbH}$ (Germany). Double distilled water was used to prepare all solutions.

A thermostated shaker (Vibramax 100 Heidolph) was used for the adsorption experiments. The shaker was set at a constant speed of $200 \mathrm{rpm}$ at room temperature $25 \pm 1{ }^{\circ} \mathrm{C}$.

Single component aqueous samples were prepared considering five different copper(II) concentrations: $1.0 \cdot 10^{-3} \mathrm{M}(63.55 \mathrm{ppm}), 2.5 \cdot 10^{-3} \mathrm{M}$ (158.875 ppm), $5.0 \cdot 10^{-3} \mathrm{M}(317.75 \mathrm{ppm}), 7.5 \cdot 10^{-3} \mathrm{M}(476.525 \mathrm{ppm})$ and $1.0 \cdot 10^{-2} \mathrm{M}(635.50 \mathrm{ppm})$. Solutions were obtained by dissolving the adequate quantity of copper nitrate, $\mathrm{Cu}\left(\mathrm{NO}_{3}\right)_{2} \bullet 2.5 \mathrm{H}_{2} \mathrm{O}$, weighed on an analytic balance with $\pm 0.0001 \mathrm{mg}$ precision, in double distilled water in a volumetric flask.

For each adsorption experiment, $50 \mathrm{~mL}$ of copper(II) solution of working concentration was put in contact with various dosages of adsorbent, from 0.25 to $2.00 \mathrm{~g}$, in a $100 \mathrm{~mL}$ beaker. Different periods of time from 5 to $240 \mathrm{~min}$ were considered to keep components in contact while stirring the mixture at constant speed (200 rpm). All operations were carried out at room temperature $\left(25 \pm 1{ }^{\circ} \mathrm{C}\right)$, at the hydrolysis $\mathrm{pH}$ of cooper(II) nitrate, approx. 5.1-5.2. The $\mathrm{pH}$ values were measured at the beginning and end of each adsorption experiment using a Multi 340i pH-meter. Since the measured values were similar, we considered a constant $\mathrm{pH}$ for all investigated solutions. In order to examine the $\mathrm{pH}$ influence on the adsorption process, the samples were adjusted to the desired values using $\mathrm{HCl}$ and $\mathrm{NaOH} 0.1 \mathrm{M}$ solutions. At the end of each specific contact time, the samples were filtered with a vacuum pump. The filtrate was used for potentiometric determination of residual copper(II) concentration.

The residual copper(II) ions concentration was potentiometrically determined using a copper-sensitive electrode ELIT 8227-NICO 2000 and a double junction reference electrode ELIT 003N—NICO 2000. According to producer 
specifications, the detection range for this copper-sensitive electrode is $0.006-6,400 \mathrm{ppm}$.

The measurement process was performed with the help of a customizable application based on Virtual Instrumentation concepts (Kovác 2004; Ionel et al. 2011). This solution was preferred mainly because of the possibility to adapt the application to the different calculus requirements (determination of sensor equation parameters, sensor output voltage inspection and automatic calculation of concentration, mean values, standard deviations, adsorption capacity and process return) involved with the experimental part.

The hardware component consisted of the NI USB 9215A data acquisition device, produced by National Instruments. This device is capable of performing ADC on 16 bits, it provides 4 analog input channels and accepts a maximum of $\pm 10 \mathrm{~V}_{\mathrm{pp}}$ for the input signal. Signal conditioning was implemented using the MCP 601 Single Supply Amplifier from MicroChip. The range of the Amplifier output voltage was $0-5 \mathrm{~V}$. Consequently, the sensitivity of this conditioning was approximately $76 \mu \mathrm{V}$. This was necessary since noise reduction/removal is an important issue in data acquisition systems (Ionel et al. 2012). Visual inspection of acquired data (with and without amplification) and also a study of the samples standard deviations demonstrated that fluctuations due to noise presence have been successfully limited when the useful signal was amplified by a gain of 10 .

The hardware device was controlled by a dedicated software application programmed in National Instruments' LabVIEW 2012 development environment. For running the software components, the authors used a notebook computer with Dual Core-1.8 GHz CPU, 2 GB DDR3 and Internet Connection.

Two important software applications were developed. The first application was used to determine the sensor response equation. The resulting linearity slopes and levels have been introduced as variables in the second software application. This second application automatically acquires data from the hardware component and presents required calculation results.

The measurement procedure was divided into three main parts: acquisition, analysis and presentation of data. This approach is consistent with VI concepts. The features of the designed software include data logging, statistical calculations and graphical presentation of recorded data. Each measurement lasts $130 \mathrm{~s}$, and the established sampling period is $1 \mathrm{~s}$. So automated calculations are performed over records of 130 samples and the following parameters are presented: sensor output voltage, sensor output average
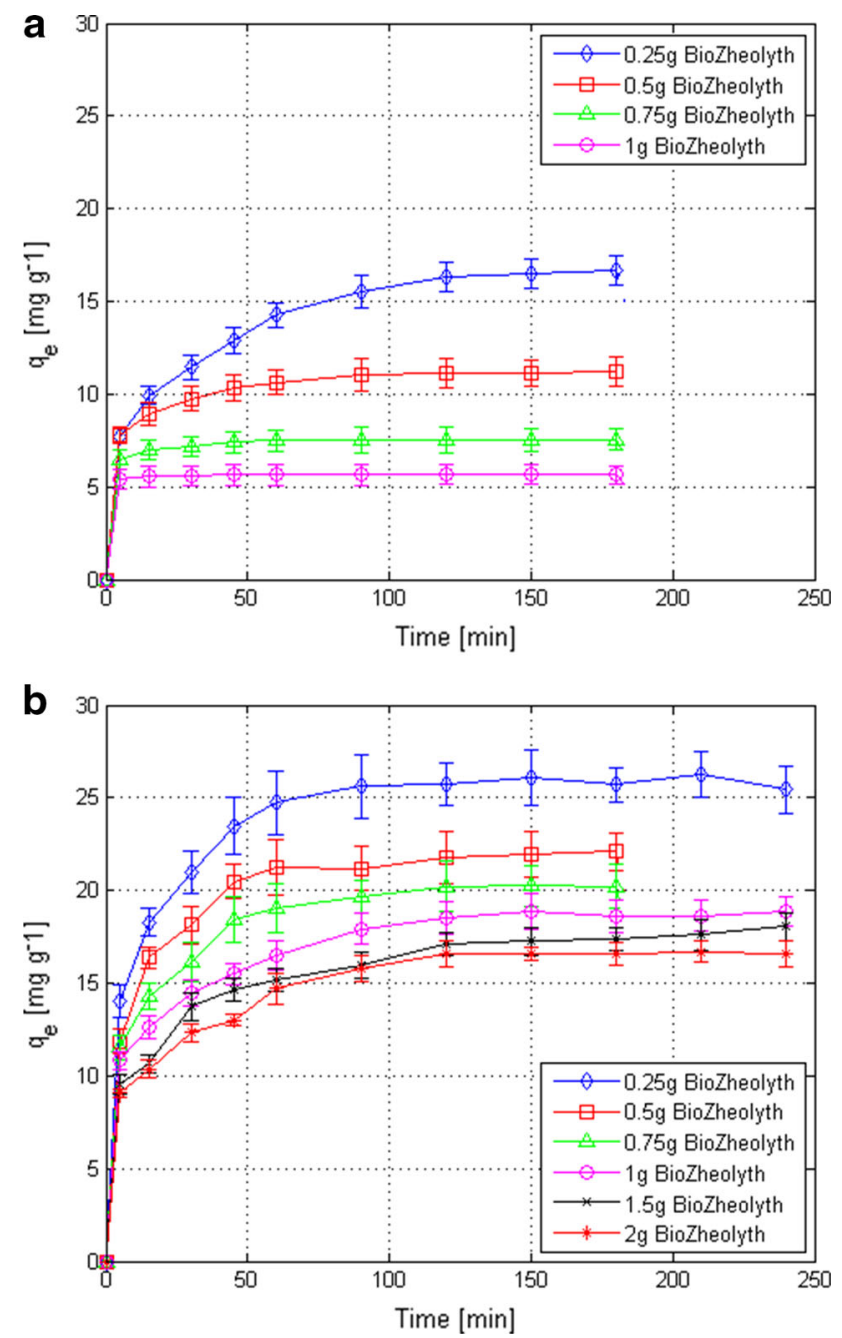

Fig. 2 Contact time effect on $\mathrm{Cu}(\mathrm{II})$ adsorption capacity of BioZheolyth; $C_{\mathrm{i} \mathrm{Cu}}=10^{-3} \mathrm{M}(\mathbf{a})$ and $C_{\mathrm{i} \mathrm{Cu}}=10^{-2} \mathrm{M}(\mathbf{b})$

voltage (over the last 10 samples), calculated concentration, adsorption capacity and process return.

For each data point, three measurement values were recorded. The mean value was considered, and the mean squared value was calculated in order to represent the error bars of each graph from Figs. 2, 3, 4, 5, 6.

\section{Adsorption equilibrium study}

Modeling of the adsorption equilibrium is an important step when assessing both the way the uptake progresses and the adsorbent properties. The distribution coefficient $K_{\mathrm{d}}$ $\left(\mathrm{mL} \mathrm{g}^{-1}\right)$ is one of the simplest models expressed as the ratio between the adsorbed copper and the amount of copper still residing in solution at equilibrium, corrected by 

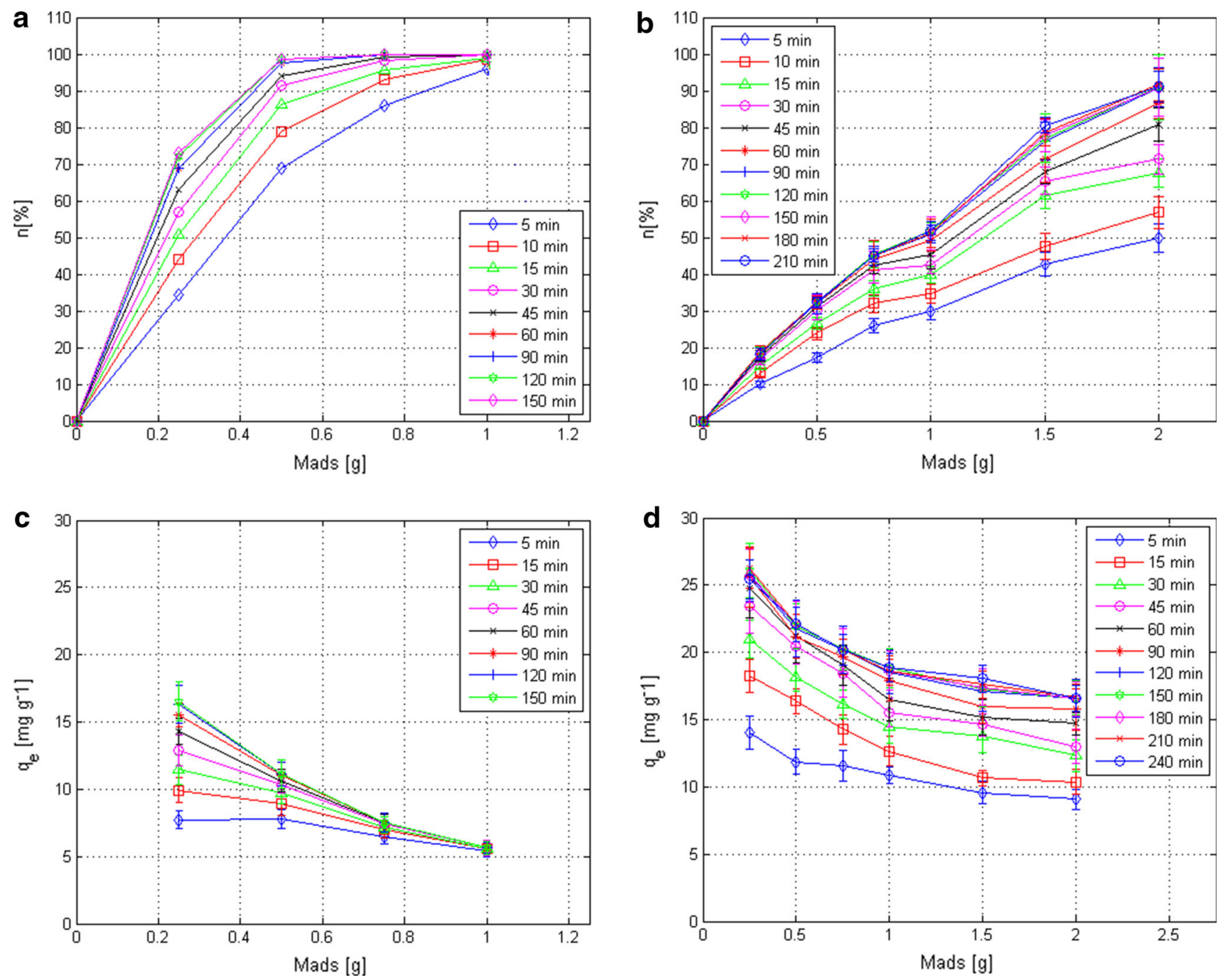

Fig. 3 Adsorbent dosage effect on $\mathrm{Cu}(\mathrm{II})$ removal degree from $C_{\mathrm{i} \mathrm{Cu}}=10^{-3} \mathrm{M}$ (a) and $C_{\mathrm{i}} \mathrm{Cu}=10^{-2} \mathrm{M}$ (b) solutions and on Cu(II) adsorption capacity from $C_{\mathrm{i} \mathrm{Cu}}=10^{-3} M(\mathbf{c})$ and $C_{\mathrm{i} \mathrm{Cu}}=10^{-2} \mathrm{M}(\mathbf{d})$ solutions

the ratio between the volume of test solution and sorbent mass (Eq. (1)) (Erdem et al. 2004).

$K_{\mathrm{d}}=\left(\frac{C_{\mathrm{i} \mathrm{Cu}}-C_{\mathrm{e} \mathrm{Cu}}}{C_{\mathrm{e} \mathrm{Cu}}}\right) \frac{V_{\mathrm{sol}}}{M_{\mathrm{ads}}}=\left(\frac{C_{\mathrm{Cu} \text { ads }}}{C_{\mathrm{e} \mathrm{Cu}}}\right) \frac{V_{\text {sol }}}{M_{\mathrm{ads}}}$

where $C_{\mathrm{i} \mathrm{Cu}}\left(\mathrm{mg} \mathrm{L}^{-1}\right)$ is the initial copper (II) concentration in the solution, $C_{\mathrm{e}} \mathrm{Cu}\left(\mathrm{mg} \mathrm{L}^{-1}\right)$ is the copper (II) concentration in solution at equilibrium, $C_{\mathrm{Cu} \text { ads }}\left(\mathrm{mg} \mathrm{L}^{-1}\right)$ is the concentration of adsorbed copper (II), $V_{\text {sol }}(\mathrm{L})$ represents the sample volume, and $M_{\text {ads }}(\mathrm{g})$ is the adsorbent mass.

The distribution coefficient $K_{\mathrm{d}}$ enables the calculation of the adsorption yield, $\eta(\%)$, according to Eq. (2).

$\eta=\frac{K_{\mathrm{d}}}{K_{\mathrm{d}}+\frac{V_{\mathrm{sol}}}{M_{\mathrm{ads}}}} \times 100$
The adsorption capacity $q_{\mathrm{e}}\left(\mathrm{mg} \mathrm{g}^{-1}\right)$, representing the copper mass retained at equilibrium onto adsorbent unit of mass, can be determined using Eq. (3).

$q_{\mathrm{e}}=\frac{\left(C_{\mathrm{i} \mathrm{Cu}}-C_{\mathrm{e} \mathrm{Cu}}\right) V_{\text {sol }}}{M_{\mathrm{ads}}}$

Adsorption isotherms are used to describe the substance distribution between adsorbent and adsorption media, at equilibrium and constant temperature. Experimentally, determined isotherms are typical for each adsorbent, adsorbate, adsorption media and temperature.

Many equations are used to fit isotherm data. Langmuir, Freundlich and Temkin are the most popular and are briefly reviewed here.

The Langmuir model (Eq. (4)) accounts for a uniform monolayer adsorption onto a homogenous surface con- 

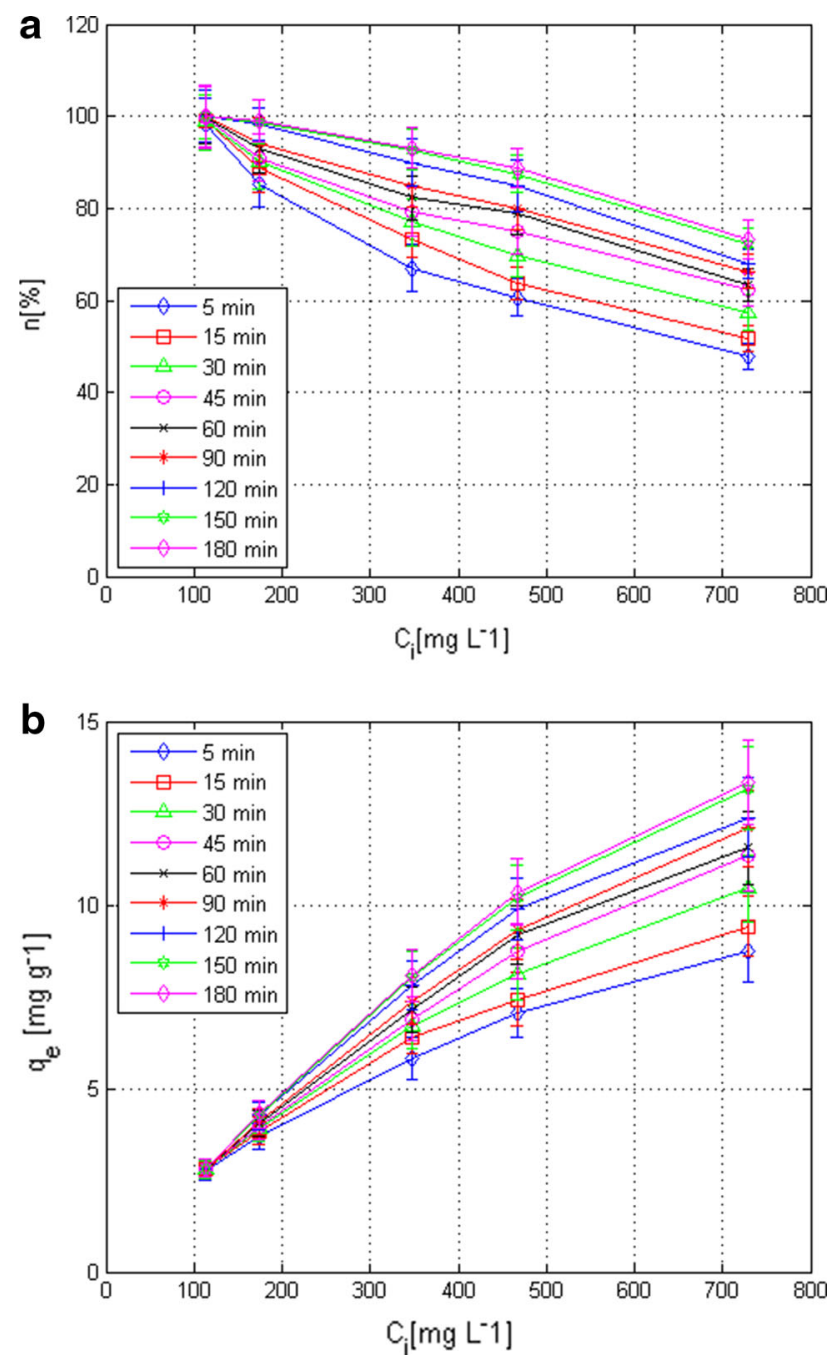

Fig. 4 Initial concentration effect on $\mathrm{Cu}$ (II) removal degree (a) and adsorption capacity (b); $m_{\mathrm{ads}}=2.00 \mathrm{~g} / 50 \mathrm{~mL}$

taining a limited number of sites, identical with regard to adsorbate affinity, without further interactions and transmutations of adsorbed molecules (Dursun et al. 2005; Hameed and Rahman 2008). In this way, the uptake is finite without being influenced by the adsorbed amount and a thermodynamic equilibrium, with constant enthalpies and activation energies, is reached after a certain contact time. Afterward, adsorption stops.

$q_{\mathrm{e}}=\frac{q_{\mathrm{max}} K_{\mathrm{L}} C_{\mathrm{e} \mathrm{Cu}}}{1+K_{\mathrm{L}} C_{\mathrm{e}}}$

where $q_{\max }\left(\mathrm{mg} \mathrm{g}^{-1}\right)$ denotes the maximum adsorption capacity, and $K_{\mathrm{L}}\left(\mathrm{mL} \mathrm{mg}^{-1}\right)$ is the Langmuir constant.

The type of adsorption that occurs can be established based on the dimensionless separation factor, $R_{\mathrm{L}}$, given by
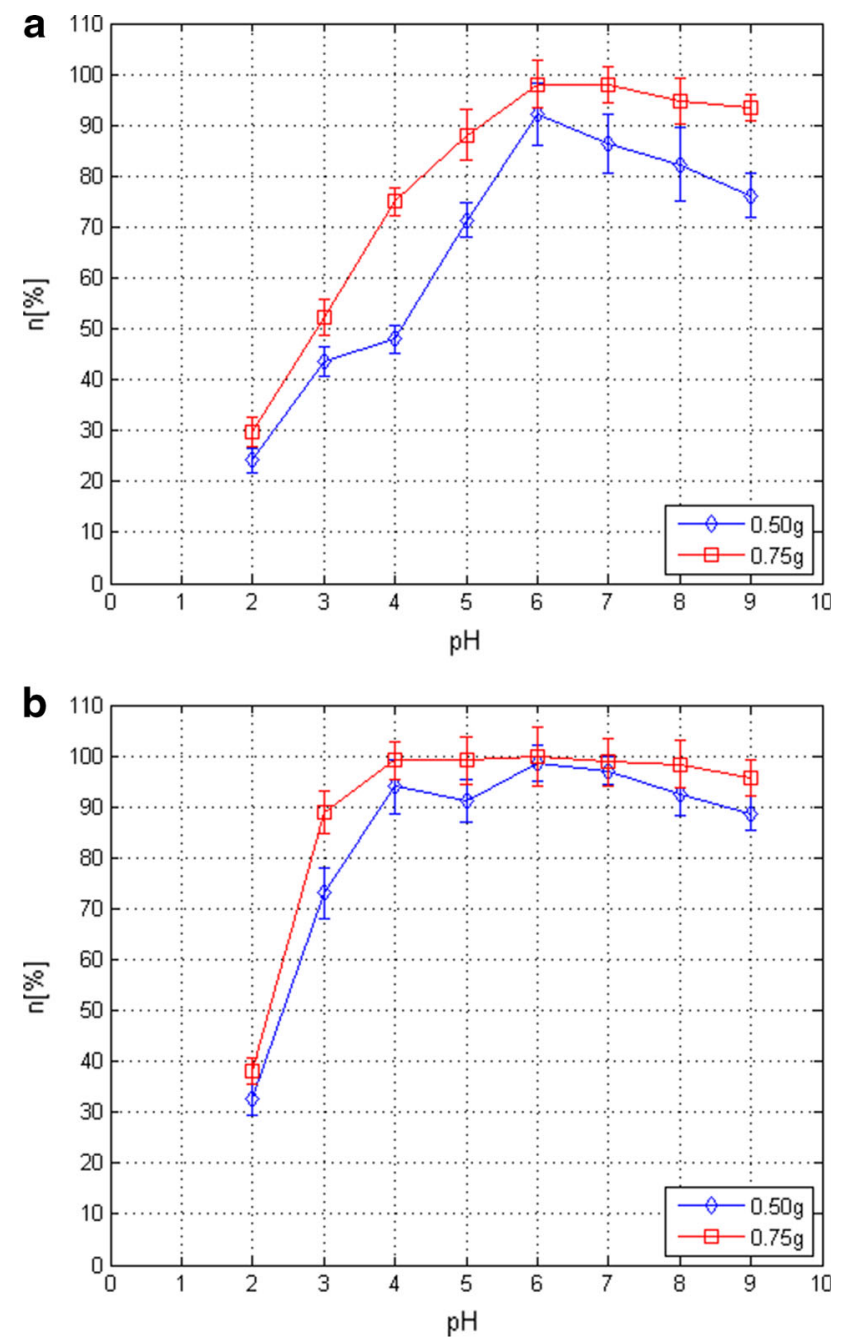

Fig. 5 pH effect on $\mathrm{Cu}$ (II) removal degree onto 0.50 and $0.75 \mathrm{~g}$ of BioZheolyth at $45 \mathrm{~min}$ (a) and $120 \mathrm{~min}$ (b) contact time

Eq. (5): unfavorable $\left(R_{\mathrm{L}}>1\right)$, linear $\left(R_{\mathrm{L}}=1\right)$, favorable $\left(0<R_{\mathrm{L}}<1\right)$ and irreversible $\left(R_{\mathrm{L}}=0\right)$ (Hameed and Rahman 2008).

$R_{\mathrm{L}}=\frac{1}{1+K_{\mathrm{L}} C_{\mathrm{e} \mathrm{Cu}}}$

Developed on empirical basis, the Freundlich model (Eq. (6)) describes a reversible non-ideal adsorption process, which is not limited to the formation of a monolayer. Adsorption occurs on a heterogeneous surface with sites that are not equivalent and/or independent. For such an adsorbent surface, Freundlich isotherm provides a better correlation coefficient than Langmuir one (Polat et al. 2006).

$q_{\mathrm{e}}=K_{\mathrm{F}} C_{\mathrm{e}}^{1 / n}$ 

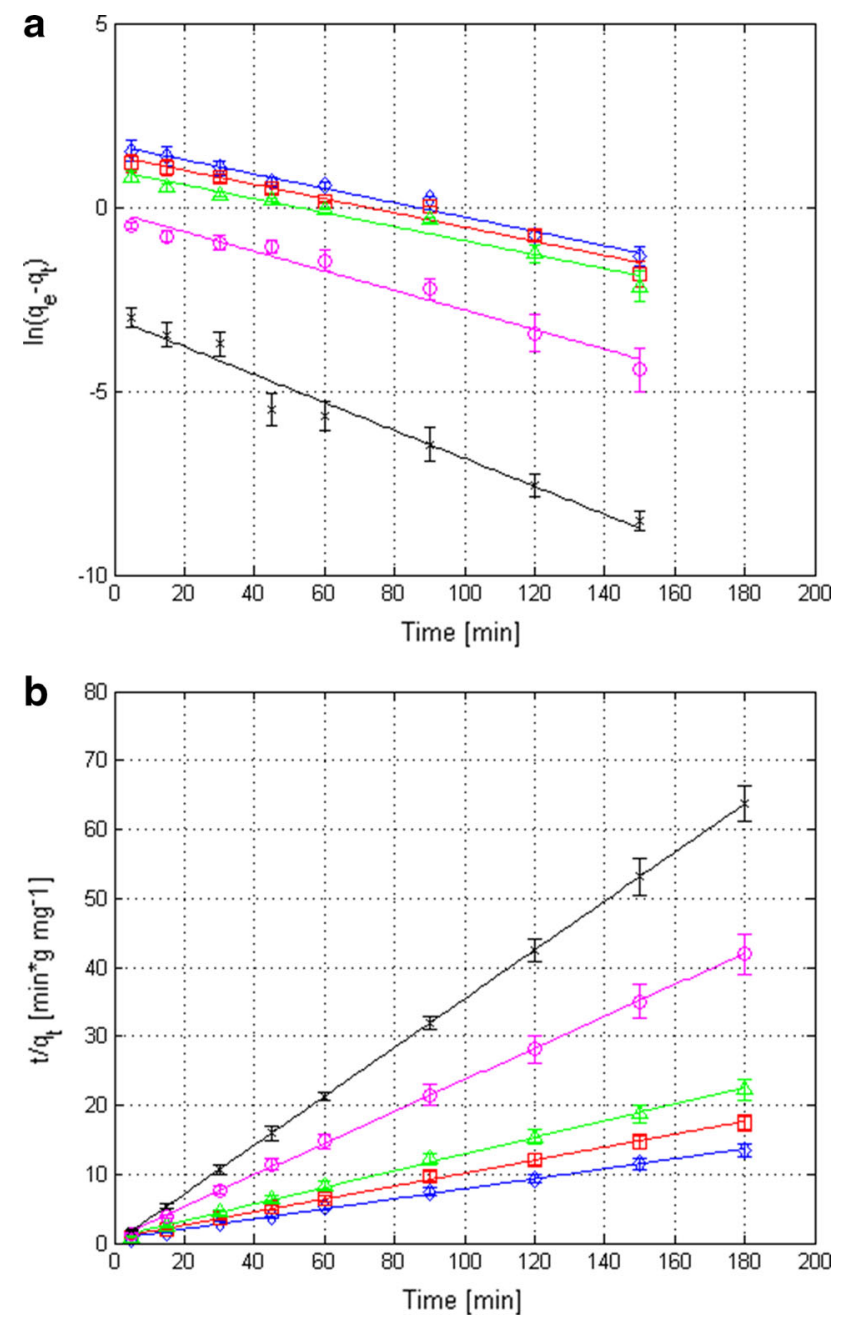

Fig. 6 Pseudo-first (a) and pseudo-second (b) order kinetics of $\mathrm{Cu}(\mathrm{II})$ adsorption onto BioZheolyth $\left(m_{\mathrm{ads}}=2.00 \mathrm{~g} / 50 \mathrm{~mL}\right.$ solution; $C_{\mathrm{i}}$ $\mathrm{Cu}=1.0 \cdot 10^{-3} \mathrm{M} \quad$ (times symbols), $2.5 \cdot 10^{-3} \mathrm{M} \quad$ (circle), $5.0 \cdot 10^{-3} \mathrm{M}$ (rectangle), $7.5 \cdot 10^{-3} \mathrm{M}$ (square), $1.0 \cdot 10^{-2} \mathrm{M}$ (diamond))

where $K_{\mathrm{F}}\left(\mathrm{mg} \mathrm{g}^{-1}\right)$ is the empirical Freundlich constant of the maximum adsorption capacity, and $1 / n$ is a factor expressing the surface heterogeneity and adsorption intensity. If the adsorption process is chemisorption, the value of $1 / n$ must be within the range $0-1$. The closer to 0 the value of $1 / n$ is, the more heterogeneous the solid surface of adsorption will be (Haghseresht and $\mathrm{Lu}$ 1998).

The Temkin isotherm model (Eq. (7)) suggests that, due to some indirect interactions between adsorbate and adsorbent, the adsorption heat of all molecules from the adsorbed layer decreases linearly with coverage (Teixeira et al. 2013). Also, this model considers that bonding energy is homogeneous for all sites of the adsorption surface.
$q_{\mathrm{e}}=\frac{R T}{b} \ln \left(K_{\mathrm{T}} C_{\mathrm{e} \mathrm{Cu}}\right)=B \ln \left(K_{\mathrm{T}} C_{\mathrm{e} \mathrm{Cu}}\right)$

where $R\left(\mathrm{~J} \mathrm{~mol}^{-1} \mathrm{~K}^{-1}\right)$ is the gas constant, $T(\mathrm{~K})$ is the absolute temperature, $b\left(\mathrm{~J} \mathrm{~mol}^{-1}\right)$ is a constant related to adsorption heat, and $K_{T}\left(\mathrm{~L} \mathrm{~g}^{-1}\right)$ is the Temkin isotherm constant.

Kinetic study

The adsorption kinetics was analyzed using the pseudo-first and pseudo-second order kinetic models in order to obtain the kinetic parameters.

The Lagergren equation for the pseudo-first order kinetics can be written as follows (Lagergren 1898):

$\mathrm{d} q_{t} / \mathrm{d} t=k_{1}\left(q_{e}-q_{t}\right)$

where $q_{t}\left(\mathrm{mg} \mathrm{g}^{-1}\right)$ is the adsorption capacity at time $t$, and $k_{1}\left(\mathrm{~J} \mathrm{~mol}^{-1} \mathrm{~K}^{-1}\right)$ is the rate constant of pseudo-first order kinetic model.

The Lagergren linearized form (Eq. (9)) allows the determination of $q_{e}$ and $k_{1}$ parameters from the slope of the line $\log \left(q_{e}-q_{t}\right)=f(t)$

$\log \left(q_{e}-q_{t}\right)=\log q_{e}-\frac{k_{1} T}{2.303}$

Equation (10) gives the kinetic parameters of the pseudosecond order model (Ho and McKay 1998):

$\frac{t}{q_{t}}=\left(\frac{1}{k_{2} q_{e}^{2}}\right)+\frac{1}{q_{e}} t$

where $k_{2}\left(\mathrm{~g} \mathrm{mg}^{-1} \mathrm{~min}^{-1}\right)$ is the rate constant of the pseudo-second order kinetic model.

The equilibrium adsorption capacity $q_{e}$ and the $k_{2}$ constant can be calculated from the slope and the intercept of the linear dependence $\frac{t}{q_{t}}=f(t)$.

\section{Results and discussion}

Adsorbents characterization

Zeolite and BioZheolyth were analyzed by FTIR and BET techniques. The results of the characterization materials were discussed by Bizerea Spiridon et al. (2013). As indicated, the difference observed between adsorbents IR spectra and also their values of surface and total pore volume is generated by the presence of cellulose in BioZheolyth.

The surface morphology of each adsorbent was assessed using the SEM-EDX analysis. The EDX data were presented in our previous paper (Bizerea Spiridon et al. 2013). 
These data attested a clinoptilolite type structure of both materials, the difference being ascribed to the presence of cellulose in BioZheolyth.

The SEM images are presented in Fig. 1. Figure 1a illustrates that zeolite lattice presents voids of large cavities. It also reveals intersecting parallel and vertical channels, made of rings of $\mathrm{Si} / \mathrm{AlO}_{4}$ tetrahedra (Margeta et al. 2013). This structure demonstrates that the zeolite used for comparison is rich in clinoptilolite. The SEM micrograph in Fig. 1b shows a fluffy structure of BioZheolyth compared to zeolite more likely due to morphological changes brought by the cellulose micro fibers, which link to zeolite particles. In this case, one can observe micro cavities that conduct to a significant increase in the adsorbent surface.

Distribution coefficient: comparison of adsorbents performances

For a first assessment of the performance of the new absorbent, BioZheolyth, against that of zeolite, the copper(II) distribution coefficients and adsorption levels were compared on both materials. For a copper(II) initial concentration of $10^{-3} \mathrm{M}$, Tables 1 and 2 reveal the distribution coefficient and the adsorption yield depending on contact time for different amounts of BioZheolyth and zeolite. The same type of data was obtained for copper(II) adsorption on BioZheolyth and zeolite, for $10^{-2} \mathrm{M}$ copper initial concentration (data not shown).

For both copper(II) initial concentrations, the experimental data reveal that regardless of the adsorbent amount and contact time, the adsorption yield is much better for BioZheolyth than zeolite. The new material performances are most likely enhanced due to the presence of cellulose, another material with well-known adsorptive properties. The $K_{\mathrm{d}}$ coefficient reflects the distribution of copper(II) between the quantity present in the solution and the quantity adsorbed by the BioZheolyth. The changes in magnitude orders are especially observed when the adsorption process reaches an equilibrium state. At this moment, an extra quantity of adsorbed copper(II) (no matter how small) induces a significant increase in the $K_{\mathrm{d}}$ value. This phenomenon is caused by a decrease in the $C_{\mathrm{eCu}}$ (see Eq. (1)). Therefore, the adsorption progress was followed on the new composite material.

Optimum conditions of copper(II) ions adsorption onto BioZheolyth

\section{Contact time effect}

The experimental results of copper ions adsorption onto BioZheolyth, for various contact times and adsorbent dosages, are shown in Fig. 2. For all investigated cases, curves are continuous and smooth thus indicating a monolayer coverage with copper ions of the sorbent outer surface.

For samples of $10^{-3} \mathrm{M}$ initial copper concentration, it can be easily observed (Tables 1, 2; Fig. 2a) that the highest adsorption (over $50 \%$ ) occurs within the first $5 \mathrm{~min}$, apart from the cases with $0.25 \mathrm{~g}$ of adsorbent. After that, both the adsorption efficiency and adsorption capacity slightly increase and tend toward equilibrium. At this stage, no further copper removal takes place. For $0.50,0.75$ and $1.00 \mathrm{~g}$ of BioZheolyth the equilibrium (over $97 \%$ adsorbed copper) is reached after 90,45 , and $15 \mathrm{~min}$, respectively. When $0.25 \mathrm{~g}$ of BioZheolyth is used, the equilibrium cannot be reached even after $150 \mathrm{~min}$.

The obtained results indicate two possible approaches regarding the optimum conditions when working with $10^{-3} \mathrm{M} \mathrm{Cu}(\mathrm{II})$ solutions: one can choose a small adsorbent quantity $\left(15 \mathrm{~g} \mathrm{~L}^{-1}\right)$ for a long period of contact (45 min) or a higher amount of adsorbent $\left(20 \mathrm{~g} \mathrm{~L}^{-1}\right)$ for a shorter contact time $(15 \mathrm{~min})$. In both cases, a removal degree above $98 \%$ can be attained.

With regard to the adsorption cases considering $10^{-2} \mathrm{M}$ initial copper concentration, Fig. $2 b$ reveals that equilibrium is reached after $60 \mathrm{~min}$ for $0.25 \mathrm{~g}$ of adsorbent, and $45 \mathrm{~min}$ for 0.50 and $0.75 \mathrm{~g}$ of adsorbent with removal degree values under $45 \%$. On higher amounts of BioZheolyth such as $1.00,1.50$ and $2.00 \mathrm{~g}$, even though the equilibrium is barely attained after $120 \mathrm{~min}$, the removal degree exceeds $45 \%$.

As a result, for $10^{-2} \mathrm{M} \mathrm{Cu}$ (II) solutions it can be recommended a $100 \mathrm{~g} \mathrm{~L}^{-1}$ adsorbent for $120 \mathrm{~min}$ contact time in order to obtain an adsorption efficiency over $90 \%$ and an adsorption capacity of $16.58 \mathrm{mg} \mathrm{g}^{-1}$.

It can be observed that for a tenfold increase in copper initial concentration, from $10^{-3} \mathrm{M}$ to $10^{-2} \mathrm{M}$ (120 min contact time), the adsorption capacity onto the same amount of BioZheolyth (i.e., $1.00 \mathrm{~g}$ ) improves from 5.65 to $18.54 \mathrm{mg} \mathrm{g}^{-1}$. Such a behavior may be attributed to the intensification of copper cations migration (penetration force) owing to the increased concentration gradient. This leads to overcoming the resistance encountered at copper(II) ions mass transfer between aqueous and solid phase.

Moreover, as shown by the above results, the initial adsorption rate (corresponding to the first 5-10 $\mathrm{min}$ ) is very high since, in the beginning, a high number of free adsorption sites are available. As these sites are filled, adsorption takes place more slowly and kinetics becomes more dependent on the rate at which adsorbate is transported from the solution mass to the empty sites (Kabuba et al. 2012). At $25^{\circ} \mathrm{C}$, after approximately $2 \mathrm{~h}$, equilibrium 
Table $1 \mathrm{Cu}(\mathrm{II})$ distribution coefficient $\left(K_{\mathrm{d}}\right)$ and removal degree $(\eta)$, for different contact times and BioZheolyth dosages, at $10^{-3} \mathrm{M} \mathrm{Cu}(\mathrm{II})$ initial concentration

\begin{tabular}{|c|c|c|c|c|c|c|c|c|}
\hline \multirow[t]{2}{*}{ Contact time (min) } & \multicolumn{2}{|c|}{$0.25 \mathrm{~g}$ BioZheolyth } & \multicolumn{2}{|c|}{$0.50 \mathrm{~g}$ BioZheolyth } & \multicolumn{2}{|c|}{$0.75 \mathrm{~g}$ BioZheolyth } & \multicolumn{2}{|c|}{$1.00 \mathrm{~g}$ BioZheolyth } \\
\hline & $K_{\mathrm{d}}\left(\mathrm{mL} \mathrm{g}^{-1}\right)$ & $\eta(\%)$ & $K_{\mathrm{d}}\left(\mathrm{mL} \mathrm{g}^{-1}\right)$ & $\eta(\%)$ & $K_{\mathrm{d}}\left(\mathrm{mL} \mathrm{g}^{-1}\right)$ & $\eta(\%)$ & $K_{\mathrm{d}}\left(\mathrm{mL} \mathrm{g}^{-1}\right)$ & $\eta(\%)$ \\
\hline 5 & 0.1042 & 34.29 & 0.2222 & 68.96 & 0.4130 & 86.10 & 1.2036 & 96.01 \\
\hline 15 & 0.1571 & 44.02 & 0.3730 & 78.86 & 0.8946 & 93.06 & 3.3797 & 98.54 \\
\hline 30 & 0.2055 & 50.69 & 0.6291 & 86.29 & 1.4584 & 95.63 & 4.8685 & 98.98 \\
\hline 45 & 0.2657 & 57.06 & 1.0891 & 91.59 & 3.4807 & 98.12 & 17.0309 & 99.71 \\
\hline 60 & 0.3429 & 63.16 & 1.6152 & 94.17 & 10.1657 & 99.35 & 31.8928 & 99.84 \\
\hline 90 & 0.4409 & 68.79 & 4.0643 & 97.60 & 43.4581 & 99.85 & 53.5772 & 99.91 \\
\hline 120 & 0.5201 & 72.23 & 7.4924 & 98.69 & 51.0975 & 99.87 & 114.6742 & 99.96 \\
\hline 150 & 0.5440 & 73.12 & 6.845 & 98.56 & 76.6430 & 99.91 & 178.7454 & 99.97 \\
\hline 180 & 0.5618 & 73.76 & 20.2773 & 99.51 & 146.7000 & 99.95 & 178.1870 & 99.97 \\
\hline
\end{tabular}

Table $2 \mathrm{Cu}(\mathrm{II})$ distribution coefficient $\left(K_{\mathrm{d}}\right)$ and removal degree $(\eta)$, for different contact times and zeolite dosages, at $10^{-3} \mathrm{M} \mathrm{Cu}(\mathrm{II})$ initial concentration

\begin{tabular}{|c|c|c|c|c|c|c|c|c|}
\hline \multirow[t]{2}{*}{ Contact time (min) } & \multicolumn{2}{|l|}{$0.25 \mathrm{~g}$ zeolite } & \multicolumn{2}{|l|}{$0.50 \mathrm{~g}$ zeolite } & \multicolumn{2}{|l|}{$0.75 \mathrm{~g}$ zeolite } & \multicolumn{2}{|l|}{$1.00 \mathrm{~g}$ zeolite } \\
\hline & $K_{\mathrm{d}}\left(\mathrm{mL} \mathrm{g}^{-1}\right)$ & $\eta(\%)$ & $K_{\mathrm{d}}\left(\mathrm{mL} \mathrm{g}^{-1}\right)$ & $\eta(\%)$ & $K_{\mathrm{d}}\left(\mathrm{mL} \mathrm{g}^{-1}\right)$ & $\eta(\%)$ & $K_{\mathrm{d}}\left(\mathrm{mL} \mathrm{g}^{-1}\right)$ & $\eta(\%)$ \\
\hline 5 & 0.0545 & 21.43 & 0.1029 & 50.73 & 0.1508 & 69.37 & 0.8466 & 94.43 \\
\hline 15 & 0.0734 & 26.85 & 0.1355 & 57.58 & 0.2147 & 76.32 & 2.1347 & 97.71 \\
\hline 30 & 0.0851 & 29.73 & 0.1480 & 59.63 & 0.2265 & 77.26 & 2.5036 & 98.04 \\
\hline 45 & 0.0918 & 31.51 & 0.1616 & 61.74 & 0.2335 & 77.79 & 2.0030 & 97.57 \\
\hline 60 & 0.0954 & 32.33 & 0.1816 & 64.50 & 0.2580 & 79.47 & 3.4554 & 98.57 \\
\hline 90 & 0.1056 & 34.59 & 0.1895 & 65.50 & 0.2777 & 80.64 & 3.3302 & 98.52 \\
\hline 120 & 0.1081 & 35.17 & 0.1898 & 65.52 & 0.2868 & 81.14 & 3.6071 & 98.63 \\
\hline 150 & 0.1127 & 36.12 & 0.1831 & 64.71 & 0.2364 & 78.01 & 4.078 & 98.79 \\
\hline 180 & 0.1107 & 35.64 & 0.1831 & 64.71 & 0.2981 & 81.73 & 3.5201 & 98.60 \\
\hline
\end{tabular}

is reached regardless the used copper initial concentration and adsorbent mass. Therefore, a contact time of $120 \mathrm{~min}$ will be considered optimal for all further investigations.

\section{Adsorbent dosage effect}

The adsorbent dosage effect on copper(II) ions removal efficiency from aqueous solution was studied using BioZheolyth concentrations ranging between 12.50 and $100.00 \mathrm{mg} \mathrm{L}^{-1}$ (0.25 and $2.00 \mathrm{~g}$ per $50 \mathrm{~mL}$ sample), while other parameters (stirring rate and contact time) were kept constant. Figure 3 illustrates the characteristics of copper ions adsorption process while changing the zeolite-cellulose composite dosage.

For samples with lower copper content $(63.55 \mathrm{ppm}$, Fig. 3a), a rapid increase in the adsorption yield can be observed. When the adsorbent dosage exceeds $0.50 \mathrm{~g}$, over
$90 \%$ of copper(II) is efficiently removed, excepting the 5 min contact case. On the other hand, adsorption capacity steadily drops for higher BioZheolyth mass to reach an almost constant value of $5.60 \mathrm{mg} \mathrm{g}^{-1}$, regardless of the time when the components are kept in contact (Fig. 3c). These results indicate that adsorption easily occurs for copper diluted solutions when the entire uniform coverage of adsorbent surface takes place more slowly. Consequently, a higher copper removal degree is reached due to small quantities of adsorbent.

For more concentrated copper solutions $\left(10^{-2} \mathrm{M}\right.$, $635.50 \mathrm{ppm}$, Fig. 3b), the process efficiency continuously increases and no plateau value is attained. This holds true even for $2.00 \mathrm{~g}$ of adsorbent. Instead, the adsorption capacity relatively quickly reaches a constant value, between 9.06 and $16.60 \mathrm{mg} \mathrm{g}^{-1}$ (Fig. 3d). This indicates that adsorption occurs rapidly within the first moments, the 
Table 3 Kinetic parameters (adsorption capacity, $q_{\mathrm{e}}$; rate constant of pseudo-first order kinetic model, $k_{1}$; rate constant of pseudo-second order kinetic model, $k_{2}$ ) of $\mathrm{Cu}(\mathrm{II})$ adsorption onto BioZheolyth and the corresponding correlation coefficient, $R^{2}$

\begin{tabular}{|c|c|c|c|c|c|c|}
\hline \multirow[t]{2}{*}{$\mathrm{Cu}(\mathrm{II})$ concentration $\left(\mathrm{mol} \mathrm{L}^{-1}\right)$} & \multicolumn{3}{|c|}{ Pseudo-first order } & \multicolumn{3}{|c|}{ Pseudo-second order } \\
\hline & $q_{\mathrm{e}}\left(\mathrm{mg} \mathrm{g}^{-1}\right)$ & $k_{1}\left(\mathrm{~J} \mathrm{~mol}^{-1} \mathrm{~K}^{-1}\right)$ & $R^{2}$ & $q_{\mathrm{e}}\left(\mathrm{mg} \mathrm{g}^{-1}\right)$ & $k_{2}\left(\mathrm{~g} \mathrm{mg}^{-1} \min ^{-1}\right)$ & $R^{2}$ \\
\hline $1.0 \cdot 10^{-3}$ & 0.04783 & 0.01650 & 0.9636 & 2.82725 & 2.23399 & 1.0000 \\
\hline $2.5 \cdot 10^{-3}$ & 0.86710 & 0.01155 & 0.9654 & 4.34972 & 0.08025 & 0.9996 \\
\hline $5.0 \cdot 10^{-3}$ & 2.67595 & 0.00825 & 0.9597 & 8.26446 & 0.01852 & 0.9979 \\
\hline $7.5 \cdot 10^{-3}$ & 3.98767 & 0.00838 & 0.9612 & 10.62699 & 0.01213 & 0.9976 \\
\hline $1.0 \cdot 10^{-2}$ & 5.33240 & 0.00847 & 0.9811 & 13.73626 & 0.00963 & 0.9977 \\
\hline
\end{tabular}

composite surface being almost entirely covered, and then it slowly continues.

In accordance with other reported data (Han et al. 2006), it can be noticed that adsorption capacity drops as the adsorbent amount increases. This behavior resides in the way in which the number of remained unsaturated sites changes during adsorption (Demirbas et al. 2009; Yahaya et al. 2011), especially after the fractional coverage of the sorbent surface. For a Langmuir adsorption mechanism, the attained plateau corresponds to a monolayer loading of adsorbent surface. When larger adsorbent amounts are added to the system, the number of free sites available for sorbent-sorbate interactions also grows. However, as adsorption capacity considers adsorption per unit of mass, the adsorbent dosage increase is much higher than adsorption itself and overall, adsorption capacity values diminish for higher amounts of BioZheolyth. Therefore, in order to completely eliminate copper ions from solution, one cannot massively increase the adsorbent mass, but has to improve other parameters such as enlargement of contact surface by increasing the number of pores or reduction in adsorbent granulation.

\section{Copper(II) initial concentration effect}

The influence of copper (II) initial concentration has been studied considering five different concentrations: $1.0 \cdot 10^{-3} \mathrm{M}(63.55 \mathrm{ppm}), 2.5 \cdot 10^{-3} \mathrm{M}(158.87 \mathrm{ppm})$, $5.0 \cdot 10^{-3} \mathrm{M}(317.75 \mathrm{ppm}), 7.5 \cdot 10^{-3} \mathrm{M}(476.52 \mathrm{ppm})$ and $1.0 \cdot 10^{-2} \mathrm{M}(635.50 \mathrm{ppm})$. Adsorption studies have been performed onto $2.00 \mathrm{~g}$ of BioZheolyth during $120 \mathrm{~min}$, the optimum conditions established for the most concentrated solution. Results are presented in Fig. 4.

The increase in initial $\mathrm{Cu}(\mathrm{II})$ concentration in solution produces different patterns of variation of the adsorption parameters. For each particular contact period, the adsorption efficiency diminishes, whereas the adsorption capacity of BioZheolyth progressively rises. This behavior seems obvious when solutions with low $\mathrm{Cu}(\mathrm{II})$ concentration are used. A small number of metal ions compete in occupying the BioZheolyth adsorption sites per unit of mass; and thus, adsorption is not dependent on metal initial concentration. When $\mathrm{Cu}$ (II) concentration increases, the free adsorption sites, for a given amount of adsorbent, are gradually occupied and consequently, the adsorption degree decreases (Kabuba et al. 2012).

\section{pH effect}

It is well known that the efficiency of metal ions adsorption from an aqueous solution onto a specific material depends on $\mathrm{pH}$ level. The $\mathrm{pH}$ value determines the metal ion speciation and also, depending on the adsorbent type, the charges load of its surface (Sprynskyy et al. 2006).

Figure 5 illustrates the $\mathrm{pH}$ effect on $\mathrm{Cu}(\mathrm{II})$ removal degree onto BioZheolyth. Samples of 0.50 and $0.75 \mathrm{~g}$ of BioZheolyth were put in contact with $10^{-3} \mathrm{M} \mathrm{Cu}$ (II) solutions for 45 and $120 \mathrm{~min}$. The system $\mathrm{pH}$ was changed by adding the appropriate amounts of $10^{-1} \mathrm{M} \mathrm{HCl}$ and $10^{-1} \mathrm{M} \mathrm{NaOH}$ solutions.

For a shorter contact time (45 min, Fig. 5a), the $\mathrm{Cu}(\mathrm{II})$ adsorption efficiency reaches a maximum value at $\mathrm{pH}$ 6.0. A solution $\mathrm{pH}$ within 2.0 and 5.0 determines a lower adsorption due to the competition with hydrogen ions. If components are kept in contact a longer period of time (120 min, Fig. 5b), the $\mathrm{Cu}$ (II) removal degree registers high values (above $98 \%$ ) for $\mathrm{pH}$ between 4.0 and 8.0. Under $\mathrm{pH} 4.0$, it presents a sharp variation and above $\mathrm{pH}$ 8.0 the variation is smooth.

The hydrogen ions are species competing against copper ions for adsorption onto BioZheolyth active sites. While $\mathrm{pH}$ increases, the hydrogen ions concentration in 
solution decreases, facilitating bigger amounts of $\mathrm{Cu}(\mathrm{II})$ ions to be absorbed (Sprynskyy et al. 2006; Dizadji et al. 2012).

A number of factors taking part in the adsorption mechanism, such as hydrated ions diameter and cations solubility, are influenced by $\mathrm{pH}$ solution. The radius of hydrated $\mathrm{Cu}$ (II) cation $(0.419 \mathrm{~nm})$ is smaller than that of many other metal cations. This fact explains the $\mathrm{Cu}$ (II) adsorption in large quantities as smaller particles can easily pass through the microporous structure of an adsorbent material. On the other hand, the amount of hydrated $\mathrm{Cu}$ (II) complex ions increases along with the increase in $\mathrm{pH}$, enhancing the adsorption (Kabuba et al. 2012)

\section{Desorption/regeneration investigation}

In order to evaluate the strength with which copper(II) is attached to the absorbent, desorption studies should be conducted. Two adsorption-desorption cycles were performed at room temperature with $50 \mathrm{~mL}$ of $10^{-2}$ and $10^{-3} \mathrm{M} \mathrm{Cu}(\mathrm{II})$ solutions in the adsorption step and with 40, 30 and $20 \mathrm{~mL}$ of $20 \mathrm{~g} \mathrm{~L}^{-1} \mathrm{NaCl}$ solution as desorption agent. The adsorptions were done following the previously established optimum conditions: $2 \mathrm{~g}$ of adsorbent and a contact time of $120 \mathrm{~min}$. The recorded percentages of desorption were 32.4 and $26.2 \%$ for $10^{-2} \mathrm{M} \mathrm{Cu}$ (II) solution and $29.1 \%$ and $27.0 \%$ for $10^{-3} \mathrm{M} \mathrm{Cu}(\mathrm{II})$ solution, respectively. The obtained results reveal that the regeneration potential of BioZheolyth is less favorable since copper(II) is hard to remove from it due to the established strong bonds. The literature mentions desorption efficiencies of copper from zeolite of $20 \%$ in $0.34 \mathrm{M} \mathrm{NaCl}$ solution at room temperature and of $50.47 \%$ in $20 \mathrm{~g} \mathrm{~L}^{-1}$ $\mathrm{NaCl}$ solution at $40{ }^{\circ} \mathrm{C}$ (Motsi 2010; Margeta et al. 2013). These relatively low desorption percentages might be caused by the electrostatic and complexation reactions occurred between the adsorbent and the metal ion. Additionally, the cellulose content of the zeolitic composite enhances the strength of the bonds hindering the ion exchange.

\section{Adsorption isotherms}

The equilibrium data of the current study were described by Langmuir, Freundlich and Temkin isotherm models. The constants characterizing the linear forms of each model for the case of $\mathrm{Cu}$ (II) ions adsorption onto $2.00 \mathrm{~g}$ of BioZheolyth for $120 \mathrm{~min}$ contact time are as follows: $q_{\max }=12.8700 \mathrm{mg} \mathrm{g}^{-1}, \quad K_{\mathrm{L}}=0.0903 \mathrm{~mL} \mathrm{mg}^{-1}$,
$R_{\mathrm{L}}=0.0452$ for Langmuir isotherm; $1 / n=0.1680$, $K_{\mathrm{F}}=4.4961$ for Freundlich isotherm; and $B=1.0253$, $K_{\mathrm{T}}=158.3735$ for Temkin isotherm.

Comparing the $R^{2}$ values of all three isotherm models for $\mathrm{Cu}$ (II) adsorption onto BioZheolyth (0.9901 vs. 0.9406 vs. 0.8474), the experimental data suggests the applicability of Langmuir model and a uniform monolayer coverage of the adsorbent surface. Furthermore, the $1 / n$ value (Freundlich model) within 0-1 range proves a strong chemisorption of copper cations onto BioZheolyth. A value of $1 / n$ closer to zero indicates that the adsorption solid surface is quite heterogeneous.

The maximum adsorption capacity of BioZheolyth under the optimum working conditions was $12.74 \mathrm{mg} \mathrm{g}^{-1}$ at $25^{\circ} \mathrm{C}$. The separation factor $R_{\mathrm{L}}$ values within $0-1$ interval show that $\mathrm{Cu}$ (II) ions adsorption is favorable on the studied material. Additionally, it may be assumed that the process tends to an irreversible behavior because the $R_{\mathrm{L}}$ value is relatively close to zero.

\section{Kinetic study}

The graphs in Fig. 6 model the pseudo-first (Fig. 6a) and pseudo-second (Fig. 6b) order kinetics for $\mathrm{Cu}$ (II) adsorption onto BioZheolyth for all cases investigated for metal initial concentration in the $10^{-3}-10^{-2} \mathrm{M}$ range.

The pseudo-second order kinetic model represents with most accuracy the experimental data, the regression coefficient being over 0.99 . Table 3 contains the kinetic parameter values of $\mathrm{Cu}$ (II) adsorption onto BioZheolyth. It can be observed that adsorption capacity values for the pseudo-second order kinetics are close to the obtained experimental ones.

\section{Conclusion}

1. In this paper, the comparative adsorption of $\mathrm{Cu}$ (II) from aqueous solutions onto zeolite and a new adsorbent based on zeolite-cellulose composite has been investigated. Synthetic $10^{-3} \mathrm{M}$ and $10^{-2} \mathrm{M} \mathrm{Cu}(\mathrm{II})$ solutions, with similar content to mining wastewaters, have been used for the adsorption studies.

2. The novel potentiometric method based on Virtual Instrumentation concept has enabled us to rapidly process and obtain experimental results for data sampled with a timing of $1 \mathrm{~s}$.

3. The adsorption assessments indicated that, regardless of the adsorbent amount and contact times, for both $10^{-3} \mathrm{M}$ and $10^{-2} \mathrm{M}$ copper initial concentrations, the 
adsorption yield is better onto BioZheolyth than onto zeolite.

4. It was established that, at room temperature, the most favorable conditions for copper adsorption onto BioZheolyth are as follows: 120 min contact time and an amount of adsorbent of $2.00 \mathrm{~g} / 50 \mathrm{~mL}$ sample.

5. The mechanisms of $\mathrm{Cu}(\mathrm{II})$ adsorption onto the new composite material based on zeolite and cellulose was well described by the Langmuir model revealing a monolayer adsorption onto a relatively heterogeneous surface, with quite strong chemical bonds.

6. The $R_{L}$ values indicated that the new zeolite-cellulose composite was favorable for $\mathrm{Cu}$ (II) adsorption from solutions of $10^{-3} \mathrm{M}$ and $10^{-2} \mathrm{M}$ concentrations.

7. Adsorption kinetics study was done using the pseudofirst and pseudo-second order models. The $\mathrm{Cu}(\mathrm{II})$ adsorption on the zeolitic composite has been observed to be most accurately described by the pseudo-second order equations.

Acknowledgments The authors acknowledge the financial support of the project HURO/0901/126/2.2.3 NETECOWAT financed by EU under the framework of Hungary-Romania Cross-border Cooperation Programme.

\section{References}

Al-Anber M, Al-Anber ZA (2008) Utilization of natural zeolite as ion-exchange and sorbent material in the removal of iron. Desalination 225(1-3):70-81. doi:10.1016/j.desal.2007.07.006

Anghel I, Grumezescu AM, Anghel AG, Chireac I, Marutescu L, Mihaiescu DE, Chifiriuc MC (2012) Antibiotic potentiator effect of the natural and synthetic zeolites with well defined nanopores with possible ENT clinical applications. Farmacia 60(5):688-695

Araya M, Pena C, Pizarro F, Olivares M (2003) Gastric response to acute copper exposure. Sci Total Environ 303(3):253-257. doi:10.1016/s0048-9697(02)00495-3

ATSDR (2004) Toxicological profile for copper. U.S. Department of Health and Human Services, Atlanta

Barakat MA (2011) New trends in removing heavy metals from industrial wastewater. Arab J Chem 4(4):361-377. doi:10.1016/j. arabjc.2010.07.019

Basaldella EI, Vázquez PG, Iucolano F, Caputo D (2007) Chromium removal from water using LTA zeolites: effect of $\mathrm{pH}$. J Colloid Interface Sci 313(2):574-578. doi:10.1016/j.jcis.2007.04.066

Bedelean H, Măicăneanu A, Stanca M, Burcă S (2009) Removal of heavy metal ions from wastewaters using natural materials. Studia Universitatis Babeş-Bolyai, Geologia 16:179-180

Bedelean H, Maicaneanu A, Burca S, Stanca M (2010) Romanian zeolitic volcanic tuffs and bentonites used to remove ammonium ions from wastewaters. Hell J Geosci 45:23-31

Bizerea Spiridon O, Preda E, Botez A, Pitulice L (2013) Phenol removal from wastewater by adsorption on zeolitic composite.
Environ Sci Pollut Res Int 20(9):6367-6381. doi:10.1007/ s11356-013-1625-x

Bostan I (2013) Economic opportunities for the exploitation of copper ore in the Romanian carpathians. Metalurgija 52(2):282-284

Butler E, Hung Y-T, Yeh RY-L, Suleiman Al Ahmad M (2011) Electrocoagulation in wastewater treatment. Water 3(2):495-525

Chaudhuri M, Kutty SRM, Yusop SH (2010) Copper and cadmium adsorption by activated carbon prepared from coconut coir. Nat Environ Pollut Technol 9(1):25-28

Cobbina SJ, Nkuah D, Tom-Dery D, Obiri S (2013) Non-cancer risk assessment from exposure to mercury $(\mathrm{Hg})$, cadmium $(\mathrm{Cd})$, arsenic (As), copper $(\mathrm{Cu})$ and lead $(\mathrm{Pb})$ in boreholes and surface water in Tinga, in the Bole-Bamboi District, Ghana. J Toxicol Environ Health Sci 5(2):29-36

De Castro Dantas TN, Neto AAD, De A, Moura MCP (2001) Removal of chromium from aqueous solutions by diatomite treated with microemulsion. Water Res 35(9):2219-2224. doi:10.1016/S0043-1354(00)00507-8

Demirbas E, Dizge N, Sulak MT, Kobya M (2009) Adsorption kinetics and equilibrium of copper from aqueous solutions using hazelnut shell activated carbon. Chem Eng J 148(2-3):480-487. doi:10.1016/j.cej.2008.09.027

Dermentzis K, Christoforidis A, Valsamidou E (2011) Removal of nickel, copper, zinc and chromium from synthetic and industrial wastewater by electrocoagulation. Int $\mathrm{J}$ Environ Sci 1(5):697-710

Dizadji N, Dehpouri S, Vossoughi SSS (2012) Experimental investigation of adsorption of heavy metals (copper (II)) from industrial wastewater with clinoptilolite. Chem Eng 29:1309-1314

Dursun G, Çiçek H, Dursun AY (2005) Adsorption of phenol from aqueous solution by using carbonised beet pulp. J Hazard Mater 125(1-3):175-182. doi:http://dx.doi.org/10.1016/j.jhazmat.2005. 05.023

ECHA (2008) Voluntary risk assessment reports-copper and copper compounds. Office of Official Publications of the European Communities, Luxembourg

Englert AH, Rubio J (2005) Characterization and environmental application of a Chilean natural zeolite. Int $\mathrm{J}$ Miner Process 75(1-2):21-29. doi:10.1016/j.minpro.2004.01.003

Erdem E, Karapinar N, Donat R (2004) The removal of heavy metal cations by natural zeolites. J Colloid Interface Sci 280(2):309-314. doi:10.1016/j.jcis.2004.08.028

Fu F, Wang Q (2011) Removal of heavy metal ions from wastewaters: a review. J Environ Manage 92(3):407-418. doi:10.1016/j. jenvman.2010.11.011

Gadhari NS, Sanghavi BJ, Srivastava AK (2011) Potentiometric stripping analysis of antimony based on carbon paste electrode modified with hexathia crown ether and rice husk. Anal Chim Acta 703(1):31-40. doi:10.1016/j.aca.2011.07.017

Gazola FC, Pereira MR, Barros MASD, Silva EA, Arroyo PA (2006) Removal of $\mathrm{Cr} 3+$ in fixed bed using zeolite NaY. Chem Eng $\mathrm{J}$ 117(3):253-261. doi:10.1016/j.cej.2005.11.014

Gupte A, Mumper RJ (2009) Elevated copper and oxidative stress in cancer cells as a target for cancer treatment. Cancer Treat Rev 35(1):32-46. doi:10.1016/j.ctrv.2008.07.004

Haghseresht F, Lu GQ (1998) Adsorption characteristics of phenolic compounds onto coal-reject-derived adsorbents. Energy Fuels 12(6):1100-1107. doi:10.1021/ef9801165

Halimoon N, Yin RGS (2010) Removal of Heavy metals from textile Wastewater using Zeolite. Environ Asia 3(2010):124-130 
Hameed BH, Rahman AA (2008) Removal of phenol from aqueous solutions by adsorption onto activated carbon prepared from biomass material. J Hazard Mater 160(2-3):576-581. doi:10. 1016/j.jhazmat.2008.03.028

Han R, Zou W, Zhang Z, Shi J, Yang J (2006) Removal of copper(II) and lead(II) from aqueous solution by manganese oxide coated sand: I. Characterization and kinetic study. J Hazard Mater 137(1):384-395. doi:10.1016/j.jhazmat.2006.02.021

Ho YS, McKay G (1998) A comparison of chemisorption kinetic models applied to pollutant removal on various sorbents. Process Saf Environ Prot 76(4):332-340. doi:10.1205/095758298529696

Horsfall M, Spiff AI (2005) Equilibrium sorption study of $\mathrm{Al}^{3+}, \mathrm{Co}^{2+}$ and $\mathrm{Ag}^{+}$in aqueous solutions by fluted pumpkin (Telfairia occidentalis HOOK f) waste biomass. Acta Chim Slov 52(2):174-181

Ionel R, Gontean A, Draut-Gherban P (2011) Implementation of a CO concentration monitoring system using virtual instrumentation. In: IEEE 6th international conference on intelligent data acquisition and advanced computing systems Prague, 15-17 Sept 2011

Ionel R, Vasiu G, Mischie S (2012) GPRS based data acquisition and analysis system with mobile phone control. Measurement 45(6):1462-1470. doi:10.1016/j.measurement.2012.03.003

Kabuba J, Mulaba-Bafubiandi A, Battle K (2012) Binary mixture of copper-cobalt ions uptake by Zeolite using neural network. World Acad Sci Eng Technol 68:1216-1221

Kaewsarn P (2002) Biosorption of copper(II) from aqueous solutions by pre-treated biomass of marine algae Padina sp. Chemosphere 47(10):1081-1085. doi:10.1016/S0045-6535(01)00324-1

Karatas M (2012) Removal of $\mathrm{Pb}(\mathrm{II})$ from water by natural zeolitic tuff: kinetics and thermodynamics. J Hazard Mater 199-200:383-389. doi:10.1016/j.jhazmat.2011.11.035

Kovác VSK (2004) Virtual instrumentation and distributed measurement systems. J Electr Eng 55(1-2):50-56

Kurniawan TA, Chan GYS, Lo W-H, Babel S (2006a) Comparisons of low-cost adsorbents for treating wastewaters laden with heavy metals. Sci Total Environ 366(2-3):409-426. doi:10.1016/j. scitotenv.2005.10.001

Kurniawan TA, Chan GYS, Lo W-H, Babel S (2006b) Physicochemical treatment techniques for wastewater laden with heavy metals. Chem Eng J 118(1-2):83-98. doi:10.1016/j.cej.2006.01. 015

Lagergren S (1898) Zur theorie der sogenannten adsorption gelöster stoffe Kungliga Svenska Vetenskapsakademiens. Handlingar 24(4):1-39

Madhava Rao M, Ramesh A, Purna Chandra Rao G, Seshaiah K (2006) Removal of copper and cadmium from the aqueous solutions by activated carbon derived from Ceiba pentandra hulls. J Hazard Mater 129(1-3):123-129. doi:10.1016/j.jhazmat. 2005.08.018

Margeta K, Logar NZ, Šiljeg M, Farkaš A (2013) Natural zeolites in water treatment-how effective is their use. In: Elshorbagy W (ed) Water treatment. InTech, Rijeka, pp 81-112

Milu V, Leroy J, Peiffert C (2002) Water contamination downstream from a copper mine in the Apuseni Mountains, Romania. Env Geol 42(7):773-782. doi:10.1007/s00254-002-0580-5

Mobin SM, Sanghavi BJ, Srivastava AK, Mathur P, Lahiri GK (2010) Biomimetic sensor for certain phenols employing a copper(II) complex. Anal Chem 82(14):5983-5992. doi:10.1021/ ac1004037
Motsi T (2010) Remediation of acid mine drainage using natural zeolite. PhD, University of Birmingham, UK

Pane L, Solisio C, Lodi A, Luigi Mariottini G, Converti A (2008) Effect of extracts from Spirulina platensis bioaccumulating cadmium and zinc on L929 cells. Ecotoxicol Environ Saf 70(1):121-126. doi:10.1016/j.ecoenv.2007.05.019

Panias D (2006) Consequences of environmental issues on sustainability of metal industries in Europe: the case study of bor. Metal J Metall 12(4):239-250

Papandreou A, Stournaras CJ, Panias D (2007) Copper and cadmium adsorption on pellets made from fired coal fly ash. J Hazard Mater 148(3):538-547. doi:10.1016/j.jhazmat.2007.03.020

Patnukao P, Kongsuwan A, Pavasant P (2008) Batch studies of adsorption of copper and lead on activated carbon from Eucalyptus camaldulensis Dehn. bark. J Environ Sci 20(9):1028-1034. doi:10.1016/S1001-0742(08)62145-2

Polat H, Molva M, Polat M (2006) Capacity and mechanism of phenol adsorption on lignite. Int J Miner Process 79(4):264-273. doi:10.1016/j.minpro.2006.03.003

Rangsayatorn N, Pokethitiyook P, Upatham ES, Lanza GR (2004) Cadmium biosorption by cells of Spirulina platensis TISTR 8217 immobilized in alginate and silica gel. Environ Int 30(1):57-63. doi:10.1016/S0160-4120(03)00146-6

Sanghavi BJ, Mobin SM, Mathur P, Lahiri GK, Srivastava AK (2013) Biomimetic sensor for certain catecholamines employing copper(II) complex and silver nanoparticle modified glassy carbon paste electrode. Biosens Bioelectron 39(1):124-132. doi:10. 1016/j.bios.2012.07.008

Santos VG, Souza JTM, Tarley CT, Caetano J, Dragunski D (2011) Copper ions adsorption from aqueous medium using the biosorbent sugarcane bagasse in natura and chemically modified. Water Air Soil Pollut 216(1-4):351-359. doi:10.1007/s11270010-0537-3

Smical I, Mihaly-Cozmuța L, Costin D (2010) Use of natural zeolites from Maramures county (Romania) in removal of $\mathrm{Cu}^{2+}, \mathrm{Pb}^{2+}$, $\mathrm{Zn}^{2+}$ ions from industrial wastewaters. Adv Environ Sci Int $\mathbf{J}$ Bioflux Soc 2(2):181-188

Solisio C, Lodi A, Torre P, Converti A, Del Borghi M (2006) Copper removal by dry and re-hydrated biomass of Spirulina platensis. Bioresour Technol 97(14):1756-1760. doi:10.1016/j.biortech. 2005.07.018

Sprynskyy M, Buszewski B, Terzyk AP, Namieśnik J (2006) Study of the selection mechanism of heavy metal $(\mathrm{Pb} 2+, \mathrm{Cu} 2+, \mathrm{Ni} 2+$, and $\mathrm{Cd} 2+$ ) adsorption on clinoptilolite. J Colloid Interface Sci 304(1):21-28. doi:10.1016/j.jcis.2006.07.068

Stankovic V, Bozic D, Gorgievski M, Bogdanovic G (2009) Heavy metal ions adsorption from mine waters by sawdust. Chem Ind Chem Eng Q 15(4):237-249. doi:10.2298/ciceq0904237s

Teixeira RNP, Sousa Neto VO, Oliveira JT, Oliveira TC, Melo DQ, Silva MAA, Nascimento RF (2013) Study on the use of roasted barley powder for adsorption of $\mathrm{Cu} 2+$ ions in batch experiments and in fixed-bed columns. Bioresources 8(3):3556-3573

Tran HH, Roddick FA (1999) Comparison of chromatography and desiccant silica gels for the adsorption of metal ions. II. Fixedbed study. Water Res 33(13):3001-3011. doi:10.1016/S00431354(99)00018-4

Tumin ND, Chuah AL, Zawani Z, Rashid SA (2008) Adsorption of copper from aqueous solution by Elais Guineensis kernel activated carbon. J Eng Sci Technol 3(2):180-189 
UNEP (2009) Mining and environment in the Western Balkans. United Nations, Geneva

Wu D, Sui Y, He S, Wang X, Li C, Kong H (2008) Removal of trivalent chromium from aqueous solution by zeolite synthesized from coal fly ash. J Hazard Mater 155(3):415-423. doi:10.1016/ j.jhazmat.2007.11.082
Yahaya NKEM, Latiff MFPM, Abustan I, Bello OS, Ahmad MA (2011) Adsorptive removal of $\mathrm{Cu}(\mathrm{II})$ using activated carbon prepared from rice husk by $\mathrm{ZnCl}_{2}$ activation and subsequent gasification with $\mathrm{CO}_{2}$. Int J Eng Technol 11(01):164-168 